\title{
PROFESIONALISME GURU SEKOLAH DASAR
}

\author{
Sukmawati $^{1}$ \\ Email : sukmawati fkip@yahoo.com
}

\begin{abstract}
Abstrak: Tuntutan profesionalisme guru adalah salah satu agenda terpenting dalam Sistem Pendidikan Nasional kita. Berdasarkan modus peraturan pemerintah tentang Standar Nasional Pendidikan, memaksa setiap pihak yang terlibat dalam sistem pendidikan untuk mempercepat peningkatan kualitas pembelajaran dan pendidikan tujuan dilakukan melalui mempersiapkan dan meningkatkan keterampilan guru profesional dan juga dengan mengelola unsur pendukung pendidikan. Dalam meningkatkan profesionalisme guru Sekolah Dasar, yang Departemen Pendidikan telah melakukan ini dengan mempersiapkan kompetensi guru Sekolah Dasar berdasarkan sebagai pedoman. Hal ini juga digunakan untuk mengukur tingkat kompetensi guru memiliki. Morever dapat digunakan sebagai pedoman dan peningkatan profesionalisme guru.
\end{abstract}

Kata-kata Kunci: Profesionalisme Guru , Standar Kompetensi, Sekolah Dasar

\begin{abstract}
Recently the demand on teacher's profesionalism is one of the most important agenda in our National Education System. Based on the regulation mode by government about the National Standard of Education, it forces every parties involved in educational system to accelerate the improvement the quality of learning and education the aims are done through preparing and improving the teachers' skill professionally and also by managing the educational supporting elements.
\end{abstract}

In improving the Elementary School teacher professionalism, the Departement of Education has done this by preparing Elementary School teacher competency based as the guideline. It is also used for measuring the competency level the teacher has. Morever it can be used as guidance and improvement of the teacher's profesionalism.

Keywords: Teacher Professionalism, Competency Standard, Elementary School

\footnotetext{
${ }^{1}$ Sukmawati adalah Dosen Jurusan Pendidikan Dasar FKIP Untan
} 
Perkembangan ilmu pengetahuan dan teknologi yang sangat pesat dalam berbagai bidang telah membawa dampak perubahan dalam kehidupan dan pola pikir masyarakat. Dampak yang yang semakin dirasakan adalah terjadinya persaingan yang semakin ketat di dalam mendapatkan hasil dan pelayanan yang semakin baik. Kemampuan mencapai hasil dan pemberian pelayanan yang baik hanya dapat dilakukan bilamana didukung oleh sumber daya manusia yang memiliki kualitas dan keahlian di dalam bidangnya. Itulah sebabnya maka tuntutan akan profesionalisme di dalam berbagai bidang atau aspek kehidupan saat ini menjadi sesuatu yang tidak lagi dapat dihindari, bahkan menjadi kebutuhan yang mendesak untuk diwujudkan.

Dalam bidang pendidikan, tuntutan terhadap kemampuan memberikan layanan yang lebih profesional khususnya dalam proses pembelajaran serta bimbingan bagi peserta didik semakin menjadi keharusan untuk dilaksanakan. Untuk mencapai tujuan pendidikan nasional yakni mencerdaskan kehidupan bangsa dan mengembangkan manusia Indonesia seutuhnya, sangat dibutuhkan peran pendidik yang profesional. Oleh sebab itu secara tegas, di dalam Undang-Undang Sistem Pendidikan Nasional (UU nomor 20 tahun 2003) dikemukakan bahwa jabatan guru sebagai pendidik merupakan jabatan profesional. Profesionalisme guru dituntut agar terus berkembang sesuai dengan perkembangan ilmu pengetahuan, teknologi dan kebutuhan masyarakat, termasuk kebutuhan terhadap sumber daya manusia yang berkualitas dan memiliki kapabilitas untuk mampu bersaing baik dalam forum regional, nasional, nasional maupun internasional.

Dalam kerangka sistem pendidikan nasional, jenjang pendidikan dasar, dan salah satu satuan pendidikannya yaitu sekolah dasar, merupakan satuan pendidikan yang sangat strategis. Hal ini utamanya dikernakan satuan pendidikan ini berperan memberikan dasar-dasar atau landasan untuk melanjutkan pendidikan pada satuan pendidikan berikutnya (sekolah menengah). Seperti disebutkan di dalam Undang-undang nomor 20 tahun 2003 pasal 17 ayat (1) bahwa pendidikan dasar merupakan jenjang pendidikan yang melandasi jenjang pendidikan menengah. Fungsi yang sangat strategis ini hanya akan dapat diwujudkan dengan baik bilamana didukung oleh kemampuan guru yang baik untuk melaksanakan seluruh fungsi pendidikan dan pembelajaran serta dukungan unsur-unsur yang lain.

Untuk memberikan arah bagi penilaian dan pembinaan kemampuan guru sekolah dasar, telah ditetapkan standar kompetensi yang merupakan pernyataan kriteria yang diperyaratkan dan ditetapkan dalam bentuk 
penguasaan pengetahuan, keterampilan dan sikap yang harus dimiliki guru yang menggambarkan kompetensi yang dimilikinya.

\section{A. Beberapa Pandangan Tentang Profesional}

Konsep, kriteria maupun standard dari suatu pekerjaan atau jabatan profesional saat ini menjadi perhatian serius berbagai pihak. Perkembangan ini terutama disebabkan karena semakin besarnya persaingan dalam mendapatkan pelayanan yang lebih baik dan kompetitif dalam upaya mencapai hasil yang optimal. Dalam bidang pendidikan langkah dan upaya menuju terwujudnya kemampuan melaksanakan tugas secara profesional bagi setiap pendidik menjadi faktor yang sangat menentukan untuk tercapainya kualitas pendidikan yang dilaksnaakan. Terlebih lagi jika dicermati dari berbagai penelitian yang menemukan bahwa ferformance dan karakteristik guru secara nyata memberikan kontribusi yang signifikan bagi keberhasilan belajar siswa (Wenglinsky, 2002: 1).

Untuk mendapatkan pemahaman yang lebih tentang pengertian atau makna profesi, pada bagian ini dipaparkan beberapa pendapat yang terkait dengan hal tersebut. Dalam salah satu tulisannya, Doyle (1990:7) mengemukakan bahwa profesi sesungguhnya menunjukkan pada pekerjaan sebagai bagian untuk mencapai suatu reputasi pada proses tingkat tinggi dari pengetahuan, keterampilan, komitmen dan sifat-sifat yang dapat dipercaya. Dalam pandangan ini profesional mengandung makna dan cakupan yang komprehensip, tidak sekedar berkenaan kemampuan, pengetahuan serta keahlian, akan tetapi juga mempersyaratkan integritas kepribadian serta komitmen seseorang. Keseluruhan kemampuan dan integritas sifat dan kepribadian tersebut menjadi satu kekuatan dalam diri seseorang untuk mewujudkan reputasi atau hasil kerja maksimal sesuai bidang tugas yang menjadi tanggung jawabnya.

Kajian tentang profesionalisme guru dapat ditemukan pada Web of Success (2003:1) melalui tulisan tentang Teachers Accountability and Professionalism. Dikemukakan bahwa profesionalisme guru merupakan suatu situasi atau peristiwa yang terbuka dan penuh kebebasan bagi guru untuk mengembangkan pembelajaran secara efektif dalam suatu standard yang tinggi dengan rasa tanggung jawab, dan mengarahkan diri sendiri dan secara terus menerus mengembangkan diri sebagai guru. Dalam keadaan ini profesionalisme utamanya ditandai oleh adanya kebebasan bagi guru guna menentukan pendekatan, strategi atau langkah-langkah yang dianggap tepat 
untuk mewujudkan suatu proses pembelajaran yang lebih berhasil guna. Upaya-upaya peningkatan kemampuan diri secara terus menerus juga merupakan faktor sangat mendasar dalam mewujudkan profesionalisme. Sebagaimana juga prinsip mendasar dari sekolah efektif prinsip pengembangan profesionalisme dalam pandangan ini meyakini bahwa upaya ini akan dapat mencapai hasil yang diharapkan bilamana guru diberikan otonomi guna mencapai kemandirian serta secara pragmatis terus berusaha menemukan metodologi yang tepat di dalam pelaksanaan tugasnya. Karena itu Morris (2001:1), dalam tulisannya yang berjudul Professionalism and Trust the Future of Teacher and Teaching, secara umum mengungkapkan bahwa tiap-tiap sekolah diharapkan dapat menciptakan atau mengembangkan suatu misi yang mendalam, termasuk misi untuk mencapai standard kualitas serta peluang secara luas bagi seluruh murid-murid dalam kerangka mewujudkan kemampuan profesional. Ini semua hanya mungkin tercapai bilamana kita (guru) dapat menempatkan kebutuhan belajar individual siswa sebagai center dari segala aktivitas yang kita lakukan. Ini juga mengandung makna bahwa guru harus selalu berupaya meningkatkan model-model lama kepada modelmodel yang lebih terbuka dan inovatif dalam seluruh area kegiatan. Tuntutan akan perlunya upaya-upaya yang lebih fleksibel dan inovatif terhadap tugastugas guru didasari beberapa visi kita masa mendatang bahwa murid-murid membutuhkan prestasi lebih tinggi dibanding waktu-waktu sebelumnya, kelas di masa yang akan datang merupakan tempat yang harus dapat menerapkan cara-cara lebih fleksibel bagi pelaksanaan proses belajar mengajar guna mendorong pencapaian tingkatan kemampuan siswa yang lebih tinggi. Hal lain yang sangat penting adalah bahwa guru-guru masa mendatang memiliki tanggung jawab dan status yang lebih tinggi serta bekerja lebih baik atau hidup lebih seimbang guna mendorong pencapaian tingkatan belajar mengajar yang lebih tinggi, serta sekolah-sekolah masa mendatang memiliki kepala sekolah yang benar-benar memiliki komitmen untuk mewujudkan perubahan ke arah yang lebih baru, lebih fleksibel dalam cara-cara kerja dalam mendorong pencapaian kualitas yang lebih tinggi.

Sullivan (2003: 4) menguraikan sebuah standard profesional adalah memiliki pengetahuan penting yang dibutuhkan, keterampilan dan sikap, di mana seluruh guru memiliki kemampuan untuk mendemontrasikannya. Bilamana guru tidak memiliki kompetensi atau tidak mampu menunjukkan etika yang dituntut untuk itu maka belum dapat dikatakan profesional dan dalam konteks kepercayaan yang tinggi guru harus dapat menunjukkan 
kemampuan terbaiknya. Secara tegas dapat dikatakan bahwa guru adalah pendidik profesional dan praktisi reflektif. Dalam kaitan ini maka guru dalam mewujudkan tanggung jawab pelaksanaan pendidikan membutuhkan keterampilan-keterampilan guna menanamkan kemampuan serta informasi sebagaimana tuntutan di dalam kurikulum. Pekerjaan tersebut juga mengharuskan guru untuk mampu mengembangkan kemampuan berfikir siswa sehingga mereka dapat berpartisipasi secara efektif dengan cara-cara yang demokratis dalam dunia orang dewasa dan juga menjadikan mereka lebih menyenangi kegiatan belajarnya.

National Board for Professional Teaching Standard (NBTS) (dalam Djahiri, 2004: 3), melalui penelitian dan kajian berbagai forum selama lebih dari 18 tahun menetapkan sejumlah acuan keahlian guru profesional berupa; (1) komitmen guru terhadap siswa dan kemampuan belajarnya, (2) penguasaan bidang studi pengajarannya berikut bagaimana cara mengajarkannya, (3) kemampuan mengelola dan memonitor pembelajaran siswanya, (4) kemampuan berfikir sistematik akan praktek pengajarannya serta memetik pengalaman dari pengalaman kerjanya, serta (5) keharusan menjadi anggota kelompok profesinya.

Beberapa pendapat sebelumnya memberikan kejelasan bahwa tugas-tugas profesional guru terkait dengan keharusan untuk memiliki pengetahuan yang memadai sesuai dengan bidang tugasnya, keterampilan-keterampilan yang diperlukan untuk mendukung proses pembelajaran serta beberapa karakteristik sikap dan kepribadian yang diperlukan. Dalam Undang-Undang RI No. 20 tahun 2003, tentang Sistem Pendidikan Nasional ditegaskan bahwa; "Pendidik merupakan tenaga profesional yang bertugas merencanakan dan melaksanakan proses pembelajaran ...". Perangkat-perangkat kemampuan untuk melaksanakan tugas sebagai guru tersebut dapat diperoleh melalui berbagai bentuk pelaksanaan fungsi kelembagaan yang memiliki tugas dan tanggung jawab mempersiapkan tenaga-tenaga guru, di samping didukung oleh kemauan yang kuat dari peserta didik itu sendiri untuk menggali sebanyak mungkin pengalaman-pengalaman yang mendukung pengetahuan, sikap dan keterampilan yang dipersyaratkan tersebut.

Di dalam Undang-undang Guru dan Dosen (Undang-yuandang nomor 14 tahun 2005), pasal 2, dijelaskan bahwa guru mempunyai kedudukan sebagai tenaga profesional pada jenjang pendidikan dasar, pendidikan menengah dan pendidikan anak usia dini pada jalur pendidikan formal yang diangkat sesuai peraturan perundang-undangan yang berlaku. Selanjutnya pada pasal 4, 
dikemukakan bahwa kedudukan guru sebagai tenaga profesional sebagaimana dimaksudkan dalam pasal 2, berfungsi meningkatkan martabat dan peran guru, sebagai agen pembelajaran berfungsi untuk meningkatkan mutu pendidikan nasional.

\section{B. Tuntutan Terhadap Profesionalisme Guru}

Pekerjaan guru adalah salah satu bidang pekerjaan yang terkait langsung dengan kebutuhan masyarakat. Oleh karena itu bilamana masyarakat semakin kritis mengamati dan menilai keberhasilan dan kegagalan tugas guru adalah sesuatu yang lumrah. Guru merupakan the front linear"nya berbagai upaya peningkatan mutu pendidikan nasional (Sa'ud, 2000:35). Demikian pula guru merupakan salah satu faktor penentu keberhasilan atau kegagalan upayaupaya peningkatan mutu dan inovasi pendidikan di tingkat sekolah (Fullan, 1992; Goodlad, 1990). Terlebih lagi saat ini masyarakat, utamanya para orang tua sangat berkepentingan dengan layanan pendidikan yang berkualitas, dan sebagian besar tanggung jawab terdepan untuk mewujudkan harapan dan citacita tersebut memang berada di pundak guru.

Dalam berbagai tulisan dan ungkapan seringkali dikemukakan bahwa meskipun kemajuan ilmu pengetahuan dan teknologi telah mencapai tarap perkembangan yang sangat mengagumkan, dan banyak jenis-jenis pekerjaan yang sebelumnya dikerjakan manusia, selanjutnya telah dapat digantikan oleh teknologi, namun tidak demikian halnya dengan tugas-tugas pendidikan. Meskipun teknologi juga sudah merambah pada dunia pendidikan, akan tetapi peranan guru tidak dapat serta merta digantikan oleh teknologi. . Dan hal ini terlebih lagi pada satuan pendidikan sekolah dasar yang sangat mebutuhkan begitu banyak perhatian dan bimbingan. Di samping itu keadaan ini juga disebabkan oleh berbagai faktor, dan faktor utamanya adalah karena tugas ini di samping terkait dengan upaya-upaya pengembangan aspek intelektual anak, juga bersentuhan langsung dengan pembentukan sikap atau kepribadian serta pengembangan keterampilan peserta didik yang tidak dapat dengan mudah dilakukan oleh peran lain. Guru merupakan kunci dalam peningkatan mutu pendidikan, dan mereka berada di titik sentral dari setiap usaha reformasi pendidikan yang diarahkan pada perubahan-perubahan kualitatif.

Pentingnya peran guru juga dibahas oleh Gaffar (1998: 4) dalam jurnal "Mimbar Pendidikan" bahwa guru memegang peranan strategis terutama dalam upaya membentuk watak bangsa melalui pengembangan kepribadian 
dan nilai-nilai yang diinginkan. Dari dimensi tersebut peran guru sulit digantikan oleh yang lain. Dipandang dari dimensi pembelajaran, peran guru dalam masyarakat Indonesia tetap dominan sekalipun teknologi yang dapat dimanfaatkan dalam proses pembelajaran berkembang amat cepat. Hal ini disebabkan karena ada dimensi-dimensi proses pendidikan, atau lebih khusus lagi proses pembelajaran yang diperankan oleh guru yang tidak dapat digantikan oleh teknologi.

Dalam ruang lingkup tugasnya, guru dituntut untuk memiliki sejumlah keterampilan terkait dengan tugas-tugas yang dilaksanakannya. Bila disimpulkan dari pendapat Wragg (1994), maka terdapat beberapa faktor yang menyebabkan semakin tingginya tuntutan terhadap keterampilan-keterampilan yang harus dikuasai dan dimiliki oleh guru. Faktor pertama adalah karena cepatnya perkembangan dan perubahan yang terjadi saat ini terutama perkembangan ilmu pengetahuan dan informasi. Implikasi bagi guru adalah di mana guru harus memiliki keterampilan-keterampilan yang cukup untuk mampu memilih topik, aktivitas dan cara kerja dari berbagai kemungkinan yang ada. Guru-guru juga harus mengembangkan strategi pembelajaran yang tidak hanya menyampaikan informasi, melainkan juga mendorong para siswa untuk belajar secara bebas dalam batas-batas yang ditentukan sebagai anggota kelompok. Mereka juga harus menemukan keseimbangan yang tepat antara tradisi dan modernitas, dan antara berbagai gagasan dan sikap yang dibawa oleh anak ke sekolah dan isi kurikulum. Jadi dengan berkurangnya kekakuan pemisahan ruang kelas dengan dunia luar, maka para guru juga perlu berusaha membawa proses belajar ke luar ruang kelas. Secara 'fisik' hal ini dilakukan dengan memberi kesempatan kepada para siswa untuk mendapatkan pengalaman-pengalaman belajar praktis pada tempat-tempat tertentu di luar sekolah, dan secara 'isi' dengan mengaitkan mata pelajaran dengan kehidupan sesehari (UNESCO, 1996: 143).

Faktor kedua adalah terjadinya perubahan pandangan di dalam masyarakat yang memiliki implikasi pada upaya-upaya pengembangan pendekatan terhadap siswa. Sebagai contoh banyak guru yang memberikan motivasi seperti mendorong anak-anak bekerja keras di sekolah agar nanti mereka memperoleh suatu pekerjaan yang baik, tidak lagi menarik bagi mereka. Dalam konteks ini gagasan tentang keterampilan mengajar yang hanya menekankan transmisi pengetahuan dapat menjadi suatu gagasan yang miskin dan tidak menarik. 
Faktor ketiga adalah perkembangan teknologi baru yang mampu menyajikan berbagai informasi yang lebih cepat dan menarik. Perkembanganperkembangan ini menguji fleksibilitas dan adaptabilitas guru untuk memodifikasi gaya mengajar mereka dalam mengakomodasi sekurangkurangnya sebagian dari perkembangan baru tersebut yang memiliki suatu potensi untuk meningkatkan proses pembelajaran. Tuntutan terhadap penguasaan sejumlah keterampilan oleh guru harus lebih mendapat perhatian., utamanya bilamana pembelajaran yang dilakukan diarahkan lebih mendalam pada pengembangan aspek-aspek sikap (afektif). Reece dan Walker (1997: 92) mempertegas pernyataannya bahwa kawasan afektif adalah daerah yang paling sulit dan relatif kurang literatur menyangkut sikap. Sikap dapat diajarkan melalui pemberian contoh, misalnya bilamana guru sering terlambat, maka siswapun akan berbuat yang sama. Dalam hal ini siswa menggunakan guru sebagai "model" dan oleh karena itu kita harus hati-hati akan hal ini. Wortham (1998: 1) dalam sebuah tulisan yang berjudul Knowledge and Action in Classroom Practice: Dialogic Approach, mengutip pernyataan Sockett bahwa pembelajaran yang baik tidak dapat dipahami terutama hanya dari sebuah pengetahuan dan keterampilan-keterampilan, sebab sentral dari pembelajaran tersebut mencakup tindakan-tindakan moral dalam konteks yang bersifat khusus. Oleh sebab itu menurut Shulman dan Sockett guru yang baik harus menggunakan penilaian terhadap tindakan situasi kelas secara khusus. Penilaian dan tindakan-tindakan guru terhadap situasi harus mencakup tindakan-tindakan siswa sebagai sumber-sumber (agen) moral.

Sebelum guru menentukan strategi pembelajaran, metode dan teknikteknik evaluasi yang akan dipergunakan, maka guru terlebih dahulu dituntut untuk memahami karakteristik siswa dengan baik. Hal ini dikarenakan dari hasil sejumlah riset menunjukkan bahwa keberagaman faktor, seperti sikap siswa, kemampuan dan gaya belajar, pengetahuan serta kemampuannya dan konteks pembelajaran merupakan komponen yang memberikan dampak sangat penting terhadap apa yang sesungguhnya harus siswa-siswa pelajari. Pengenalan terhadap siswa dalam interaksi belajar mengajar, merupakan faktor yang sangat mendasar dan penting untuk dilakukan oleh setiap guru agar proses pembelajaran yang dilakukan dapat menyentuh kepentingan siswa, minat-minat mereka, kemampuan serta berbagai karakteristik lain yang terdapat pada siswa, dan pada akhirnya dapat mencapai tujuan pembelajaran yang diharapkan. Pengenalan terhadap siswa mengandung arti bahwa guru harus dapat memahami dan menghargai keunikan cara belajar siswa dan 
kebutuhan-kebutuhan perkembangan mereka. Upaya-upaya mengenal dan memahami siswa merupakan kegiatan yang berlangsung secara terus menerus, karena kebutuhan siswa tidak bersifat menetap, akan tetapi mengalami perubahan sesuai dengan tahap-tahap perkembangannya. Bahkan seringkali perubahan-perubahan yang terjadi pada siswa berlangsung dengan cepat sehingga guru tidak jarang mengalami kesulitan untuk dapat mengenal dan memahaminya secara cermat. Di samping itu pula kebutuhan-kebutuhan mereka menggambarkan keragaman intelegensial, kemampuan maupun ketidakmampuannya. Bagi anak-anak yang memiliki kualitas intelegensi yang baik dan berada dalam tahap atau masa perkembangan tertentu memiliki sejumlah kebutuhan yang berbeda dengan anak-anak yang tergolong memiliki intelegensi yang rendah walaupun sama-sama berada pada tahap perkembangan tertentu.

Michael Grinder, pengarang Righting the Education Conveyor Belt (DePorter \& Henacki, 2001: 112), telah mengajar gaya-gaya belajar dan mengajar kepada banyak instruktur. Ia mencatat bahwa dalam setiap kelompok yang terdiri dari tiga puluh murid, sekitar dua puluh dua orang mampu belajar secara cukup efektif dengan cara-cara visual, auditorial dan kinestetik sehingga mereka tidak membutuhkan perhatian khusus. Dari sisa delapan orang, sekitar enam orang memilih satu modalitas belajar dengan sangat menonjol melebihi dua modalitas lainnya. Sehingga setiap saat mereka harus selalu berusaha keras untuk memahami perintah, kecuali jika perhatian khusus diberikan kepada mereka dengan menghadirkan cara yang mereka pilih. Dua orang murid lainnya mempunyai kesulitan belajar karena sebab-sebab ekternal. Hal ini memberikan isyarat tentang betapa pentingnya pengetahuan guru, khususnya guru-guru sekolah dasar tentang karakteristik perbedaan siswa yang lebih lanjut memungkinkan guru untuk dapat memilih dan menentukan pendekatanpendekatan pembelajaran guna mmendukung tercapainya hasil belajar siswa secara optimal.

\section{Standar Kompetensi Guru Sekolah Dasar}

Untuk dapat melaksanakan perannya dengan baik, setiap guru dituntut untuk memiliki sejumlah kemampuan yang dipersyaratkan, baik berkenaan dengan aspek pengetahuan, sikap serta keterampilan yang diperlukan. Berbekal kemampuan-kemampuan tersebut diharapkan guru semakin mampu memahami serta melaksanakan tugas dan tanggung jawab yang harus dilaksanakannya. Bilamana guru telah mampu memahami bidang tugasnya dengan baik, serta 
mampu pula melaksanakan tugas-tugas tersebut sesuai standard yang diharapkan dengan akumulasi kepribadian yang sesuai dengan jabatannya, maka diyakini akan semakin mendukung terwujudnya tugas profesional sebagai seorang guru seperti diharapkan.

Profesionalisme guru sangat terkait dengan kemampuan mewujudkan atau mengaktualisasikan kompetensi yang dipersyaratkan bagi setiap guru. Kompetensi diartikan sebagai pengetahuan, keterampilan, dan nilai-nilai dasar yang direfleksikan dalam kebiasaan berpikir dan bertindak. Arti lain dari kompetensi adalah spesifikasi dari pengetahuan, keterampilan, dan sikap yang dimiliki seseorang serta penerapannya di dalam pekerjaan, sesuai dengan stndar kinerja yang dibutuhkan oleh lapangan (Dirjen Dikdasmen, 2004:4). Kompetensi yang dimiliki guru akan menunjukkan kualitas guru yang sebenarnya . Kompetensi tersebut akan terwujud dalam bentuk penguasaan pengetahuan, keterampilan mapun sikap profesional dalam menjalankan tugasnya. Oleh sebab itu Standar Kompetensi Guru dapat diartikan sebagai suatu pernyataan tentang kriteria yang dipersyaratkan, ditetapkan dan disepakati bersama dalam bentuk pengetahuan pengetahuan, keterampilan dan sikap bagi seorang tenaga kependidikan sehingga alayak disebutu kompeten (Dirjen Dikdasmen, 2004:4).

Standar kompetensi guru mempunyai arti yang sangat penting terutama sebagai dasar untuk melakukan penilaian terhadap tingkat kompetensi minimal kemampuan guru. Hal ini lebih lanjut akan dapat menjadi kerangka dasar untuk melakukan pembinaan lebih lanjut dari setiap guru sehingga secara bertahap dapat mencapai standar yang diharapkan.

Dalam Peraturan Pemerintah No. 19 tahun 2005 pasal 28, ayat 3 disebutkan bahwa kompetensi sebagai agen pembelajaran pada jenjang pendidikan dasar dan menengah serta pendidikan anak usia dini meliputi; (1) kompetensi pedagogik, (2) kompetensi kepribadian, (3) kompetensi profesional, dan (4) kompetensi sosial.

Kompetensi pedagoogik adalah kemampuan mengelola pembelajaran peserta didik yang meliputi pemahaman terhadap peserta didik, perancangan dan pelaksanaan pembelajaran, evaluasi hasil beljar, dan pengembangan peserta didik untuk mengaktualisasikan berbagai potensi yan dimilikinya. Kompetensi kepribadian adalah kemampuan kepribadian yang mantap, stabil, dewasa, arif dan berwibawa, menjadi teladan bagi peserta didik, dan berakhlak mulia. Kompetensi profesional adalah kemampuan penguasaan materi pelajaran secara luas dan mendalam yan memungkinkannya membimbing 
peserta didik memenuhi standar kompetensi yang ditetapkan dalam Standar Nasional Pendidikan. Sedangkan kompetensi sosial adalah kemampuan pendidik sebagai bagian dari masyarakat untuk berkomunikasi dan bergaul secara efektif dengan peserta didik, sesama pendidik, tenaga kependidikan, orang tua/wali peserta didik, dan masyarakat sekitar.

Dalam naskah Standar Kompetensi Guru Sekolah Dasar yang diterbitkan oleh Departemen Pendidikan Nasional melalui Direktorat Jenderal Pendidikan Menengah (2004), merumuskan Standar Kompetensi Guru Sekolah dasar meliputi komponen kompetensi pengelolaan pembelajaran dan wawasan kependidikan, komponen kompetensi akademik/vokasional, dan komponen pengembangan profesi.

Sub komponen kompetensi pengelolaan pembelajaran, mencakup aspek aktivitas atau kemampuan; (1) menyusun rencana pembelajaran, (2) melaksanakan pembelajaran, (3) menilai prestasi belajar peserta didik, (4) melaksanakan tindak lanjut hasil penilaian prestasi belajar peserta didik. Sedangkan sub komponen kompetensi wawasan kependidikan meliputi; (1) memahami landasan kependidikan, (2) memahami kebijakan pendidikan, (3) memahami tingkat perkembangan siswa, (4) memahami pendekatan pembelajaran yang sesuai materi pembelajarannya, (5) menerapkan kerjasama dalam pekerjaan, (6) memanfaatkan kemajuan IPTEK dalam pendidikan. Komponen kompetensi akademik/vokasional yaitu menguasai keilmuan dan keterampilan sesuai materi pembelajaran. Sedangkan komponen kompetensi pengembangan kompetensi, yaitu mengembangkan profesi.

Masing-masing kompetensi yang tercakup di dalam kompetensi pengelolaan pembelajaran yang terdiri dari enam butir sub kompetensi sebagaimana disebutkan di atas lebih lanjut dijabarkan lagi ke dalam sejumlah sub-sub kompetensi yang lebih spesifik. Secara rinci penjabaran ke dalam subsub kompetensi dapat dilihat pada naskah Standar Kompetensi Guru Sekolah Dasar oleh Departemen Pendidikan Nasional.

Komponen kompetensi akademik/vokasional mencakup kompetensi menguasai keilmuan dan keterampilan sesuai materi pembelajaran atau menguasai materi pembelajaran sesuai bidangnya.

Kompetensi pengembangan profesi bagi guru sekolah dasar meliputi kemampuan; (a) menulis karya ilmiah hasil penelitian/pengkajian/survei/ evaluasi di bidang pendidikan, (b) menulis karya ilmiah berupa tinjauan atau ulasan ilmiah hasil gagasan sendiri di bidang pendidikan sekolah, (c) menulis tulisan ilmiah populer di bidang pendidikan sekolah pada media massa, (d) 
menulis prasaran/makalah berupa tinjauan, gagasan atau ulasan ilmiah yang disampaikan pada pertemuan ilmiah, (e) menulis buku pelajaran/modul/diktat, (f) menulis diktat pelajaran, (g) menemukan teknologi tepat guna, (h) membuat alat pelajaran/alat peraga atau alat bimbingan, (i) menciptakan karya seni monumental/seni pertunjukan, (j) mengikuti kegiatan pengembangan kurikulum.

Selain dari penguasaan kompetensi dan sub kompetensi sebagaimana di atas, kompetensi guru juga dinilai sesuai dengan kompetensi pembelajaran bidang studi masing-masing yang diajarkan. Kemampuan mewujudkan setiap kompetensi sesuai indikator yang ditetapkan merupakan standar kemampuan yang harus dimiliki setiap guru. Dengan penetapan standar kompetensi ini maka kemampuan profesional guru semakin dimungkinkan untuk diukur guna keperluan pembinaan dan peningkatan lebih lanjut.

\section{DAFTAR PUSTAKA}

Departemen Pendidikan Nasional. (2004). Standar Kompetensi Guru Sekolah Dasar. Depdiknas Dirjen Dikdasmen.

DePorter, B \& Hernacki, M. (2001). "Quantum Learning, Membiasakan Belajar Nyaman dan Menyenangkan" (Alwiyah Abdurrahman, Penerjemah). Bandung: Kaifa.

Djahiri K. (2004). Membina dan Meningkatkan Profesionalisme Tugas Peran Pendidik Melalui Peningkatan Kompetensi Guru Serta Sekolah Sebagai Pusat Pembelajaran \& Agent of Changes. Bandung: UPI

Doyle, Wr. (1990). "Thema in Teacher Education Research" dalam Handbook of Research on Teacher Education, A Project of the Association of Teacher Educators (1990). New York: Macmillan Publishing Company.

Fullan, M. (1992). The New Menaning of Educational Change. Toronto: OISE Pres Publishing Co.

Gaffar, F.G. (1998). "Menghargai Pengabdian Para Guru”. Dalam Mimbar Pendidikan, Jurnal Pendidikan (3, XVII).

Goodlad, J.I. (1990). Teachers for Internation's Schools. SanFransisco: Jossey Bass Publishing Co.

Morris, Rt Hon E. (2001). "Professionalism and Trust - the Future of Teachers and Teaching". SME Departemen for Education and Skill. (Online). Tersedia: http://www.askatl.org.uk/Pdfs/121101.Pdf 
Peraturan Pemerintah Nomor 19 tahun 2005, tentang Standar Nasional Pendidikan.

Reece, I, dan Walker, S. (1997). Teaching training and learning A Practical Guide (Third Edition). Great Britain: Biusiness Education Publisher Limited.

Sa'ud, Udin S. (2000). "Standarisasi Lulusan dan Program Pendidikan Prajabatan Guru Profesional Sebuah Harapan". Dalam Mimbar Pendidikan, Jurnal Pendidikan (3, XIX 2000).

Sullivan, K. (2003). Teachers Standards and Professionalism: Contested Perspectives in a Decade of Reform. (Online). Tersedia: http://www. Aare.edu.au/99pap/sul99090.htm.

Unesco The International Commission on Education for the Twenty-first Century. (1996). Treasure Within. Paris: Unesco Publishing.

Undang-Undang RI Nomor 20 tahun 2003 tentang Sistem Pendidikan Nasional.

Web of Success. (2003). Teachers Accountability and Professionalism. (Online). Tersedia: http://www.mdk12.org/process/benchmark/ improve/web of success/teacheers.html.

Wenglinsky, H. (2002). "How Shools Matter: The Link Between Teacher Classroom Practices and Student AcademicPerformance" Eduaction Policy Analysis Archieve. (Online). Tersedia: http://epaa.asu.edu/ epaa/v10n12/. 